\title{
PENGGUNAAN ARANG UNTUK MENGURANGI KADAR HISTAMIN IKAN PINDANG TONGKOL BATIK (Euthynnus affinis)
}

\author{
Subaryono, Farida Ariyani dan Dwiyitno")
}

\begin{abstract}
ABSTRAK
Penelitian penambahan arang pada proses pemindangan ikan tongkol batik (Euthynnus affinis) untuk menurunkan kadar histamin sudah dilakukan. Bahan baku yang digunakan dibiarkan semalam pada suhu kamar untuk meningkatkan kadar histaminnya. Konsentrasi arang yang ditambahkan dalam proses pemindangan sebesar 1, 3 dan 5\% dari bobot ikan. Parameter yang diamati meliputi kadar air, kadar histamin, kadar TVB, organoleptik, jumlah bakteri pembentuk histamin, kadar protein dan kadar lemak. Hasil penelitian menunjukkan bahwa penambahan $5 \%$ arang dalam proses pemindangan dapat menurunkan kadar histamin pindang dari 140,5 mg/ $100 \mathrm{~g}$ bahan menjadi $88,6 \mathrm{mg} / 100 \mathrm{~g}$ bahan. Perlakuan ini juga menurunkan angka TVB produk dari $34,4 \mathrm{mgN} / 100 \mathrm{~g}$ bahan menjadi $28,0 \mathrm{mgN} / 100 \mathrm{~g}$ bahan pada penambahan $5 \%$ arang. Selain itu perlakuan penambahan arang pada konsentrasi $3 \%$ atau lebih dapat meningkatkan nilai penampakan dan mampu menghilangkan rasa gatal yang diakibatkan oleh keberadaan histamin pada produk.
\end{abstract}

\section{ABSTRACT: The use of charcoal to reduce histamine content in boiled salted eastern little} Tuna (Euthynnus affinis). By: Subaryono, Farida Ariyani and Dwiyitno

Research on the charcoal addition in the processing of boiled salted eastern little tuna fish (Euthynnus affinis) to reduce histamine content has been carried out. The raw material was stored at room temperature overnight to increase its histamine content. Concentration levels of charcoal added were 1, 3 and $5 \%$ of fish weight. Parameters observed were moisture content, histamine content, TVB content, organoleptic acceptability, histamine producing bacteria, protein content and fat content. The results showed that charcoal addition in the processing of boiled salted tuna decreased the histamine content from $140.5 \mathrm{mg} / 100 \mathrm{~g}$ (control) to $88.6 \mathrm{mg} / 100 \mathrm{~g} \mathrm{(5 \%}$ charcoal addition). The treatment also decreased TVB value from $34.4 \mathrm{mgN} / 100 \mathrm{~g}$ (control) to 28.0 mgN/100g (5\% charcoal addition). Meanwhile, 3\% charcoal addition also improved organoleptic appearance and removed the undesirable taste because of histamine.

KEYWORDS: charcoal, histamine, organoleptic, little tuna

\section{PENDAHULUAN}

Pada beberapa jenis ikan, khususnya dari famili scombroidae yang memiliki daging merah, kerusakan oleh aktivitas bakteri maupun enzim dapat menghasilkan racun yang disebut scombrotoksin. Scombrotoksin adalah toksin yang dihasilkan oleh aktivitas bakteri terutama pada ikan-ikan famili scombroidae seperti tuna, cakalang, tongkol, marlin, mackerel dan sejenisnya (Hardy \& Smith, 1976). Senyawa yang bersifat racun tersebut antara lain adalah histamin, yang merupakan suatu senyawa hasil perombakan asam amino bebas histidin. Histidin diubah menjadi histamin oleh enzim histidine decarboxylase yang dihasilkan oleh bakteri-bakteri pembentuk histamin (Rawles et al., 1995). Beberapa jenis ikan diketahui banyak mengandung histidin bebas, baik yang termasuk dalam kelompok skombroid seperti cakalang, marlin, dan sardin, maupun yang termasuk dalam kelompok nonskombroid seperti mahi-mahi (Coryphaena hippurus) dan dolpin. Ikan albakor (Thunnus albacores) dan kahawai (Arripis trutta) diketahui mempunyai kadar histidin bebas yang sangat tinggi, mencapai lebih dari $1000 \mathrm{mg}$ setiap $100 \mathrm{~g}$ ikan (Fletcher et al., 1995). Histidin bebas terdapat lebih banyak dalam daging merah/gelap dibandingkan dengan pada daging putih, dan oleh karenanya kecepatan pembentukan dan akumulasi histamin juga lebih cepat terjadi pada daging merah (Kim et al., 1999).

Kandungan histamin pada ikan segar umumnya di bawah $10 \mathrm{mg} / 100 \mathrm{~g}$ (Ozogul et al., 2004). Kandungan histamin antara $50-100 \mathrm{mg} / 100 \mathrm{~g}$ umumnya sudah dianggap berbahaya dan dapat mengakibatkan keracunan pada orang yang

-) Peneliti pada Pusat Riset Pengolahan Produk dan Sosial Ekonomi Kelautan dan Perikanan 
mengkonsumsinya (Wonggo, 1995). Beberapa negara telah menetapkan batasan kandungan histamin pada produk-produk perikanannya, misalnya Amerika Serikat, Swedia dan Chekoslovakia menetapkan kandungan histamin maksimal 50 mg/100 g (Ababouch, 1991).

Kenyataan di lapangan menunjukkan bahwa kualitas ikan yang baru didaratkan dari kapal maupun ikan yang akan diolah oleh pengolah di beberapa daerah penangkapan di Indonesia sebagian sudah tidak segar lagi. Hal ini disebabkan karena waktu melaut yang cukup lama ditambah dengan kondisi pendinginan yang tidak baik memungkinkan kerusakan oleh aktivitas bakteri maupun enzim terus berlangsung selama proses penangkapan, pendaratan, pelelangan maupun selama pemasaran ikan segar tersebut. Meskipun kondisi kesegaran ikan tersebut sudah tidak baik, umumnya beberapa pengolah tetap mengolah ikan tersebut menjadi produk ikan asin atau pindang. Anggawati et al. , (1984) melaporkan bahwa kandungan histamin pada produk pindang cakalang yang ada di pasaran cukup tinggi yaitu 72,48 - 89,16 $\mathrm{mg} / 100 \mathrm{~g}$. Sementara itu kandungan histamin pada ikan peda yang dilaporkan oleh Sarnianto et al., (1984) sebesar 107,32-133,43 mg/100g. Hasil pengamatan kadar histamin ikan cakalang yang digunakan sebagai bahan baku pindang di Pelabuhan Ratu sebesar 289,7 $\mathrm{mg} / 100 \mathrm{~g}$ bahan dan $247,6 \mathrm{mg} / 100 \mathrm{~g}$ pada produk pindangnya. Tingginya kadar histamin pada produkproduk tersebut dapat menyebabkan terjadinya keracunan histamin. Oleh karena itu teknik pengolahan yang mampu menurunkan kadar histamin sampai batas aman untuk dikonsumsi sangat dibutuhkan oleh pengolah guna meningkatkan jaminan keamanan pangan produk olahannya

Selama ini penelitian untuk menurunkan kadar histamin pada ikan belum banyak dilakukan, dan umumnya baru upaya untuk mempertahankan agar kadar histamin dalam bahan baku tetap rendah dengan pendinginan. Penelitian ini dilakukan dengan harapan dapat menurunkan kandungan histamin produk pindang yang dihasilkan dari bahan baku yang sudah tinggi kadar histaminnya, dengan cara penambahan arang yang diduga dapat menyerap beberapa senyawa beracun. Dipilinnya arang dalam penelitian ini karena arang telah digunakan untuk menghilangkan rasa gatal pada pindang yang diolah dari bahan baku yang sudah buruk oleh beberapa pengolah di Pelabuhan Ratu. Akan tetapi sejauh mana efek penurunan kadar histamin dalam produk pindang sampai saat ini belum diketahui. Apabila proses ini berhasil menurunkan kandungan histamin sampai batas aman untuk dikonsumsi diharapkan resiko keracunan senyawa ini menjadi lebih kecil. Dengan ditemukannya teknik pengolahan pindang yang mampu menurunkan kadar histamin sampai batas aman, diharapkan dapat menjadi alternatif pemanfaatan ikan yang sudah tidak segar menjadi produk olahan yang aman untuk dikonsumsi, sehingga pemanfaatan hasil perikanan menjadi lebih optimal

\section{BAHAN DAN METODE}

Bahan baku penelitian adalah ikan tongkol batik (Euthynnus affinis) segar yang diperoleh dari hasil penangkapan kapal satu hari melaut dengan alat mini purse seine di Pelabuhan Ratu, Jawa Barat. Ikan tersebut dimasukkan ke dalam coolbox yang diberi es hancuran dan dibawa ke Laboratorium Pusat Riset Pengolahan Produk dan Sosial Ekonomi Kelautan dan Perikanan Jakarta. Untuk melihat efek penggunaan arang dalam menurunkan histamin pada proses pemindangan, kadar histamin bahan baku dinaikkan terlebih dahulu dengan cara membiarkan sampel pada suhu kamar $\left(28-32^{\circ} \mathrm{C}\right)$ selama satu malam di dalam coolbox tertutup tanpa pemberian es.

Terhadap bahan baku dilakukan pengamatan kadar air, kadar histamin, kandungan total volatile base (TVB), jumlah bakteri pembentuk histamin, dan kadar protein. Selanjutnya sampel disiangi dan dicuci untuk membersihkan lendir, isi perut dan insang. Pindang yang digunakan dalam penelitian ini adalah pindang naya. Naya yang telah diisi ikan sebanyak 3-4 ekor/ naya, disusun dalam dandang stainless steel dan direbus dalam air garam 15\% (b/v) mendidih selama 30 menit. Penambahan arang dilakukan dengan cara meletakkan arang sebanyak 1, 3 dan 5\% dari bobot ikan di dasar naya pada waktu proses pemindangan. Arang yang dipakai adalah arang kayu dari jenis kayu campuran yang dihaluskan dan diseragamkan dengan ukuran volume bongkahan sekitar $0,5 \mathrm{~cm}^{3}$. Arang yang dipergunakan adalah arang yang biasa dipergunakan oleh beberapa pengolah untuk menghilangkan rasa gatal pada ikan pindang. Kondisi arang sebelum dihaluskan berbentuk bongkahan yang tidak seragam dengan ukuran volume tiap bongkah sekitar $3-6 \mathrm{~cm}^{3}$ yang diperoleh dari Pelabuhan Ratu, Jawa Barat. Selain itu dilakukan pula pengolahan pindang tanpa penambahan arang sebagai kontrol.

Parameter yang diamati untuk produk pindang meliputi kadar air, kadar histamin, kandungan TVB, bakteri pembentuk histamin, nilai organoleptik, kadar protein dan kadar lemak. Pengukuran TVB dilakukan dengan metode Conway (Siang \& Kim, 1992). Kadar histamin diukur dengan metode Hardy and Smith (1976), dengan pengukuran serapan histamin menggunakan alat spektrometer pada panjang gelombang $495 \mathrm{~nm}$. Untuk menumbuhkan bakteri pembentuk histamin digunakan media Niven yang dimodifikasi oleh Anggawati et al., (1984). Analisis 
kadar air, kadar protein dan kadar lemak mengikut metode standar AOAC (AOAC, 1980). Uji organoleptik dilakukan dengan melibatkan panelis sebanyak 10 orang dengan parameter pengamatan meliputi rupa, bau, rasa, tekstur, lendir dan penerimaan seperti pada Lampiran 1.

Rancangan percobaan yang dipakai adalah rancangan acak lengkap faktor tunggal dengan 3 kali ulangan. Analisis data dilakukan dengan anova dan apabila berbeda nyata dilanjutkan dengan uji beda nyata terkecil (LSD) (Steel \& Torrie, 1989).

\section{HASIL DAN BAHASAN}

\section{Bahan Baku}

Hasil analisis terhadap ikan tongkol batik (Euthynnus affinis) yang digunakan sebagai bahan baku setelah dibiarkan semalam pada suhu kamar disajikan pada Tabel 1. Dari hasil tersebut terlihat bahwa setelah ikan tongkol batik (Euthynnus affinis) dibiarkan selama semalam pada suhu kamar, nilai histamin sudah sangat tinggi yaitu sebesar 213,9 mg/ $100 \mathrm{~g}$ bahan. Kondisi ini sesuai dengan kenyataan di lapangan khususnya untuk kejadian dimana hasil tangkapan melimpah dan nelayan membawa es yang tidak sebanding dengan hasil tangkapan yang diperoleh sehingga sebagian ikan tidak dies sampai didaratkan. Hasil pengamatan menunjukkan kadar histamin bahan baku ikan pindang cakalang di Pelabuhan Ratu mencapai 289,7 mg/100 g bahan. Tingginya kandungan histamin ini disebabkan karena aktivitas bakteri dan enzim yang berperan dalam memproduksi histamin secara maksimum (Frank et al., 1981). Nilai histamin ini sudah sangat tinggi di atas ambang aman untuk dikonsumsi karena menurut Wonggo (1995), kadar histamin 50 - 100 mg/100 g bahan sudah dianggap berbahaya dan dapat menyebabkan keracunan pada orang yang mengkonsumsinya.

Kadar histamin ikan yang dipakai sebagai indikator tingkat kerusakan dan persyaratan bagi kesehatan masyarakat di berbagai negara (USA, Kanada, Jerman, Denmark, dan Swedia) berbeda-beda tetapi umumnya berkisar antara 50 - $100 \mathrm{mg} / 100 \mathrm{~g}$. Food and Drug Administration Amerika Serikat (USFDA) mensyaratkan batas maksimal kadar histamin pada ikan segar sebesar 50 mg/100 g, sedangkan kadar di atas $50 \mathrm{mg} / 100 \mathrm{~g}$ merupakan indikasi mulai terjadinya dekomposisi (Fletcher et al., 1998). Dengan demikian nilai kadar histamin ikan yang telah dibiarkan selama semalam pada suhu kamar tersebut sudah jauh lebih tinggi dari persyaratan untuk ikan segar.

Jumlah bakteri pembentuk histamin juga cukup tinggi yaitu 3,8 $810^{7} \mathrm{koloni} / \mathrm{g}$. Hal ini disebabkan karena pada suhu kamar perkembangan bakteri pembentuk histamin tidak terhambat, disamping itu jenis ikan tongkol ini memiliki kandungan daging merah yang cukup tinggi yang biasanya mengandung cukup banyak senyawa histidin bebas di dalamnya, sehingga merupakan media yang baik untuk pertumbuhan bakteri pembentuk histamin. Menurut Fletcher et al. (1995), kandungan histidin bebas pada ikan-ikan scombroidae seperti ikan albacore (Thunnus albacores) dan kahawai (Arripis trutta) sangat tinggi mencapai lebih

Tabel 1. Hasil analisis kimia dan mikrobiologi ikan tongkol batik (Euthynnus affinis)

Table 1. Results of chemical and microbiological analysis of eastern little tuna (Euthynnus affinis)

\begin{tabular}{lc}
\hline \multicolumn{1}{c}{ Parameter/Parameter } & Nilai/Value \\
\hline Kadar air/Moisture content (\%) & 79.4 \\
Kadar histamin/Histamine content $(\mathrm{mg} / 100 \mathrm{~g})$ & 213.9 \\
Kandungan TVB/Total volatile base content $(\mathrm{mgN} / 100 \mathrm{~g})$ & 37.6 \\
Jumlah total bakteri pembentuk histamin/ Total & $3.8 \times 10^{7}$ \\
histamine producing bacteria (cfu/g) & 24.7 \\
Kadar protein/Protein content (\%) & \\
\hline
\end{tabular}

penguraian histidin menjadi histamin yang bekerja optimal pada suhu kamar $\left(28-32^{\circ} \mathrm{C}\right)$. Suhu optimum untuk produksi histamin dari beberapa jenis ikan berkisar antara $20-30^{\circ} \mathrm{C}$ (Sally et al., 1980, Masayo et al., 1981), tetapi pada cakalang (skipjack tuna) diperlukan suhu yang lebih tinggi $\left(37,7^{\circ} \mathrm{C}\right)$ untuk dari 1000 mg/100g daging. Kadar air dan protein ikan tongkol batik seperti dalam ikan segar pada umumnya yaitu berturut-turut sebesar $79,4 \%$ dan $24,7 \%$.

Nilai total basa menguap (TVB) bahan baku yang dibiarkan semalam pada suhu kamar juga relatif tinggi yaitu $37,6 \mathrm{mgN} / 100 \mathrm{~g}$ bahan. Nilai ini menunjukkan 
bahwa kondisi bahan sudah tidak segar lagi, karena nilai TVB ikan segar paling tinggi $30 \mathrm{mgN} / 100 \mathrm{~g}$ bahan (Sikorski et al., 1990).

\section{Pindang Tongkol}

Data kadar air, histamin dan TVB produk ikan pindang dapat dilihat dalam Tabel 2. Dari data tersebut terlihat bahwa kadar air produk ikan pindang untuk semua perlakuan hampir sama yaitu sekitar $64-65 \%$.
Penurunan kadar histamin ini kemungkinan disebabkan karena kemampuan arang dalam menyerap (mengabsorpsi) atau menjerap (mengadsorpsi) histamin melalui kesetimbangan dalam larutan garam. Banyaknya ruang pori dalam arang memungkinkan bahan ini menyerap partikelpartikel yang sangat halus dan menjebaknya di dalam pori tersebut sampai pori-pori ini jenuh (Anon., 2002). Banyaknya pori dalam arang menyebabkan bahan ini memiliki luas permukaan yang sangat tinggi (500 -

Tabel 2. Hasil analisis kimia produk ikan pindang

Table 2. Results of chemical analysis of boiled salted fish product

\begin{tabular}{lccc}
\hline Periakuan/Treatment & Air/Moisture (\%) & $\begin{array}{c}\text { HistaminiHistamine } \\
(\mathbf{m g} / \text { / 00g) }\end{array}$ & $\begin{array}{c}\text { TVB/Total volatile } \\
\text { base (mgN/100g) }\end{array}$ \\
\hline $\begin{array}{l}\text { Kontrol/Control } \\
\text { Penambahan 1\% arang/ }\end{array}$ & $65.02 \pm 0.35$ & $140.47 \pm 11.50$ & $37.60 \pm 3.67$ \\
$\begin{array}{l}1 \% \text { charcoal addition } \\
\text { Penambahan 3\% arang/ }\end{array}$ & $64.67 \pm 0.34$ & $94.26 \pm 10.99$ & $31.68 \pm 4.26$ \\
$3 \%$ charcoal addition & & & \\
$\begin{array}{l}\text { Penambahan 5\% arang/ } \\
5 \% \text { charcoal addition }\end{array}$ & $65.17 \pm 0.65$ & $88.56 \pm 8.04$ & $29.76 \pm 3.32$ \\
\hline
\end{tabular}

Secara statistik $(p=0,05)$ variansi keempat perlakuan ini tidak berbeda nyata, tetapi dibandingkan ciengan bahan baku $(79,41 \%)$ semua perlakuan ini secara nyata lebih rendah. Dengan demikian proses pemindangan menururkan kadar air produk sekitar $14 \%$. Hal ini disebabkan pada proses pemindangan terjadi koagulasi protein yang mengakibatkan turunnya kemampuan menahan air (water holding capacity), sehingga air dalam jaringan daging tidak lagi tertahan dan terlepas keluar. Selain itu karena media perebus yang digunakan adalah larutan garam, maka terjadi proses difusi garam ke dalam jaringan daging dan mendorong keluarnya air dalam jaringan tersebut.

Penambahan arang pada proses pengolahan ikan pindang sangat nyata pengaruhnya $(p=0,05)$ terhadap penurunan kadar histamin produk, yaitu pada penambahan arang sebanyak $5 \%$ dari bobot ikan dapat menurunkan kadar histamin pindang menjadi 88,56 $\mathrm{mg} / 100 \mathrm{~g}$ dari $140,47 \mathrm{mg} / 100 \mathrm{~g}$ pada produk kontrol. Perlakuan penambahan arang dengan konsentrasi $3 \%$ sudah memberikan pengaruh yang nyata $(p=0,05)$ dalam menurunkan kadar histamin produk menjadi $94,26 \mathrm{mg} / 100 \mathrm{~g}$ dari $140,47 \mathrm{mg} / 100 \mathrm{~g}$ pada produk tanpa penambahan arang (kontrol). Sementara itu antara perlakuan penambahan arang dengan konsentrasi $3 \%$ dan $5 \%$ tidak berbeda nyata.
$15000 \mathrm{~m}^{2} / \mathrm{g}$ arang), sehingga sangat efektif untuk menyerap partikel-partikel yang halus tersebut. Proses penyerapan ini hanya akan efektif apabila histamin berada dalam fase terlarut, sehingga proses pemindangan ini diduga terlebih dahulu menyebabkan terlarutnya histamin dari jaringan daging ke larutan perebus

Proses terlarutnya histamin ke dalam larutan perebus terjadi akibat adanya proses koagulasi protein pada waktu pemindangan yang menyebabkan turunnya daya mengikat air protein sehingga air terlepas dari jaringan otot. Selain itu adanya perbedaan tekanan osmose antara air perebus (air garam) dengan air dalam jaringan ikan akan meriyebabkan terjadinya proses difusi garam ke dalam jaringan dan terdorongnya air keluar dari jaringan daging. Keluarnya air dari jaringan daging ikan akan melarutkan histamin yang ada dalam jaringan ke larutan perebus. Pada perlakuan kontrol, proses penyerapan histamin dari larutan perebus tidak terjadi sehingga kemungkinan terjadinya penyerapan kembali histamin dari larutan perebus oleh produk pindang lebih besar. Secara statistik $(p=0,05)$ penambahan arang dengan konsentrasi $1 \%$ dari bobot bahan baku tidak berpengaruh nyata pada penurunan kadar histamin produk. Hal ini kemungkinan disebabkan karena jumlah arang yang ditambahkan terlalu sedikit 
sehingga efek penyerapan histamin tidak cukup optimal untuk menurunkan kadar histamin produk dan terjadi reabsorbsi histamin dari air perebus ke produk pindang. Apabila dibandingkan dengan kadar histamin bahan baku sebesar $213,93 \mathrm{mg} / 100 \mathrm{~g}$ maka proses pemindangan itu sendiri sudah menurunkan kadar histamin menjadi $140,47 \mathrm{mg} / 100 \mathrm{~g}$. Hal ini menunjukkan bahwa terekstraknya histamin dalam jaringan daging ikan ke dalam larutan perebus telah terjadi karena adanya proses koagulasi protein dan difusi garam yang menyebabkan keluarnya air dari jaringan daging beserta histamin di dalamnya. Keluarnya air dari jaringan daging ini dapat dilihat dari perbedaan kadar air yaitu untuk bahan mentah sebesar $79,41 \%$ sedangkan pindang antara 64,19 $65,17 \%$

Dari data nilai TVB produk pindang, terlihat bahwa perlakuan penambahan arang pada proses pemindangan juga dapat menurunkan kadar TVB produk meskipun relatif kecil. Secara statistik $(p=$ 0,05 ) hanya perlakuan penambahan arang dengan konsentrasi $5 \%$ saja yang berbeda nyata dibanding produk kontrol. Perlakuan penambahan arang dengan konsentrasi 1 dan $3 \%$ tidak secara nyata menurunkan kadar TVB produk. Produk pindang dengan penambahan $5 \%$ arang masih bisa diterima berdasar nilai TVB-nya, karena batas penerimaan kandungan TVB untuk ikan yang dikonsumsi adalah $30 \mathrm{mgN} \%$ (Sikorski et al, 1990). Penurunan nilai TVB ini kemungkinan disebabkan oleh efek penyerapan senyawa-senyawa basa menguap ke dalam pori-pori arang selama proses pemindangan berlangsung. Efek penyerapan ini tidak melibatkan beda muatan molekul, sehingga partikel halus apa saja bisa terserap ke dalam pori-pori arang tersebut selama pori-pori ini belum jenuh.

Pengaruh penambahan arang pada proses pemindangan terhadap nilai organoleptik produk dapat dilihat dalam Tabel 3. Dari data tersebut terlihat bahwa perlakuan penambahan arang pada proses pemindangan ternyata mampu meningkatkan nilai organoleptik khususnya penampakan dan rasa produk, bahkan untuk penambahan arang pada konsentrasi 3 dan 5\% juga meningkatkan nilai penerimaan produk. Hal ini disebabkan penampakan produk pindang dengan penambahan arang terlihat menjadi lebih bersih dibanding kontrol. Tidak terdapat perbedaan nyata $(p=0,05)$ antara perlakuan penambahan arang pada konsentrasi 1,3 dan $5 \%$ terhadap nilai penampakan. Meskipun demikian, dibanding produk tanpa penambahan arang (kontrol) nilai organoleptik penampakan ini lebih tinggi dan berbeda secara nyata, sehingga dapat disimpulkan bahwa perlakuan penambahan arang ini untuk semua konsentrasi memperbaiki nilai penampakan. Hal ini diduga karena kemampuan arang dalam menyerap partikel-partikel kecil dalam larutan garam yang digunakan pada proses pemindangan, sehingga menyebabkan larutan garam menjadi lebih jernih dan produk akhir yang diperoleh juga lebih bersih.

Penambahan arang juga memperbaiki nilai organoleptik rasa karena panelis dapat mendeteksi rasa gatal pada produk tanpa penambahan arang akibat tingginya kadar histamin dalam produk Sebagian besar panelis masih mendeteksi adanya rasa gatal pada produk pindang yang pada proses pemindangannya ditambahkan arang dengan konsentrasi $1 \%$. Semakin tinggi konsentrasi arang yang ditambahkan pada proses pemindangan cenderung menurunkan rasa gatal pada produk sehingga nilai organoleptik rasa semakin tinggi. Pada proses pemindangan dengan penambahan arang sebesar 3 dan $5 \%$ dari bobot bahan baku, sebagian besar panelis sudah tidak dapat mendeteksi lagi adanya rasa gatal pada produk. Dengan demikian perlakuan penambahan arang ini mampu meningkatkan penerimaan produk pindang

Data jumlah bakteri pembentuk histamin pada produk pindang dapat dilihat dalam Tabel 4 . Jumlah bakteri pembentuk histamin pada bahan baku cukup

Tabel 3. Pengaruh penambahan arang terhadap nilai organoleptik ikan pindang

Table 3. Effect of charcoal addition on the organoleptic value of boiled salted fish

\begin{tabular}{lcccc}
\hline \multirow{2}{*}{ Parameter/Parameter } & Kontroll & \multicolumn{3}{c}{ Penambahan arang/Charcoal addition (\%) } \\
\cline { 3 - 5 } & Control & $\mathbf{1}$ & $\mathbf{3}$ & $\mathbf{5}$ \\
\hline Penampakan/Appearance & 2.8 & 3.4 & 3.2 & 3.6 \\
Bau/Odor & 4 & 4 & 4 & 3.8 \\
Rasa/Taste & 2.9 & 3.3 & 3.6 & 4.8 \\
Tekstur/Texture & 4.4 & 4.4 & 4.3 & 4.5 \\
Lendir/Slime & 4.7 & 4.8 & 4.9 & 4.4 \\
Penerimaan/Acceptance & 3.5 & 3.5 & 3.9 & 3.9 \\
\hline
\end{tabular}

* catatan/note: skala/scale 1 - 5 
Tabel 4. Pengaruh penambahan arang terhadap bakteri pembentuk histamin ikan pindang Table 4. Effect of charcoal addition on the total histamine producing bacteria of boiled salted fish

\begin{tabular}{lc}
\hline \multicolumn{1}{c}{ Perlakuan/Treatment } & $\begin{array}{c}\text { Jumlah bakteri pembentuk hista min/ } \\
\text { Total histamine producing bacteria (cfu/g) }\end{array}$ \\
\hline Bahan baku/raw material & $3.8 \times 10^{7}$ \\
Kontrol/control & $7.3 \times 10^{3}$ \\
Penambahan arang 1\%/ & $10.7 \times 10^{3}$ \\
1\% charcoal addition & \\
Penambahan arang 3\%/ & $12.3 \times 10^{3}$ \\
3\% charcoal addition & \\
Penambahan arang 5\%/ & $9.0 \times 10^{3}$ \\
5\% charcoal addition & \\
\hline
\end{tabular}

tinggi yaitu sekitar $10^{7} \mathrm{koloni} / \mathrm{g}$ bahan dan menurun dengan adanya proses pemindangan menjadi kurang dari $10^{4} \mathrm{koloni} / \mathrm{g}$ bahan. Penurunan jumlah bakteri pembentuk histamin ini disebabkan karena sebagian bakteri mati selama pemanasan pada proses pengolahan pindang. Suhu perebusan yang digunakan pada proses pemindangan adalah suhu air garam mendidih $\left(\geq 100^{\circ} \mathrm{C}\right)$ dengan waktu perebusan selama 30 menit, sehingga cukup untuk mematikan sebagian bakteri pembentuk histamin. Perlakuan penambahan arang dengan berbagai konsentrasi tidak berpengaruh nyata terhadap jumlah bakteri pembentuk histamin. Jumlah bakteri pembentuk histamin pada produk kontrol maupun produk dengan penambahan arang semuanya hampir sama yaitu sekitar $10^{3}-10^{4} \mathrm{sel} / \mathrm{g}$ bahan. Meskipun jumlah bakteri pembentuk histamin ini tidak berbeda nyata untuk semua perlakuan $(p=$ 0,05 ), tetapi kadar histamin produk berbeda nyata pada penambahan arang dengan konsentrasi 3 dan $5 \%$. $\mathrm{Hal}$ ini menunjukkan bahwa kadar histamin dalam produk lebih dipengaruhi oleh proses penyerapan histamin yang sudah terbentuk dengan adanya poripori dalam arang dibanding oleh perbedaan jumlah bakteri pembentuk histamin.

Hasil analisis kadar protein produk pindang menunjukkan bahwa perlakuan penambahan arang untuk semua konsentrasi tidak memberikan pengaruh nyata $(p=0,05)$, yaitu untuk produk kontrol, penambahan 1,3 , dan $5 \%$ arang memiliki kadar protein berturut-turut sebesar 25,$06 ; 25,39 ; 24,13$ dan $23,79 \%$. Hal ini menunjukkan bahwa adanya kecenderungan penurunan kandungan protein pada ikan pindang dapat diabaikan. Kadar lemak produk ikan pindang kontrol, dengan penambahan 1,3 , dan $5 \%$ arang berturut-turut sebesar 0,$83 ; 0,88 ; 0,85$ dan $0,91 \%$. Perlakuan penambahan arang pada proses pengolahan pindang tersebut tidak memberikan pengaruh nyata $(p=0,05)$ terhadap kadar lemak produk yang dihasilkan. Hal ini menunjukkan bahwa penambahan arang tidak menyebabkan perubahan kadar lemak yang berarti.

\section{KESIMPULAN DAN SARAN}

\section{Kesimpulan}

1. Perlakuan penambahan arang pada proses pemindangan mampu menurunkan kandungan histamin, yaitu dengan penambahan sebanyak 3 dan $5 \%$ dari bobot bahan baku mampu menurunkan kadar histamin produk berturut-turut menjadi 94,26 dan $88,56 \mathrm{mg} / 100 \mathrm{~g}$ bahan dari 140,47 pada produk kontrol.

2. Meskipun penambahan arang sebanyak 3 dan $5 \%$ pada pengolahan pindang mampu menurunkan kadar histamin produk, tetapi apabila kadar histamin bahan baku sudah sangat tinggi maka perlakuan ini tidak mampu menurunkan histamin sampel hingga kadar yang aman untuk dikonsumsi

3. Penambahan arang sebanyak $5 \%$ juga menurunkan nilai TVB dari $37,6 \mathrm{mgN} / 100 \mathrm{~g}$ pada produk kontrol menjadi $29,76 \mathrm{mgN} / 100 \mathrm{~g}$. Perlakuan ini tidak berpengaruh terhadap kadar air, kadar protein dan kadar lemak produk.

4. Perlakuan penambahan arang meningkatkan nilai organoleptik penampakan dan menghilangkan rasa gatal.

5. Penambahan arang tidak berpengaruh terhadap penurunan jumlah bakteri pembentuk histamin, tetapi proses pemindangan itu sendiri telah menurunkan jumlah bakteri ini dari sekitar $10^{7}$ koloni / g bahan menjadi $10^{4} \mathrm{koloni} / \mathrm{g}$ bahan.

\section{Saran}

Untuk menurunkan kandungan histamin pada pindang dapat dilakukan dengan penambahan arang sebanyak $5 \%$, selama kandungan awal histaminnya 
tidak lebih dari $120 \mathrm{mg} / 100 \mathrm{~g}$ bahan. Dengan demikian upaya pemberlakuan mata rantai dingin semenjak ikan ditangkap merupakan langkah yang paling baik untuk mencegah terjadinya keracunan histamin.

\section{DAFTAR PUSTAKA}

Ababouch, L. 1991. Histamine food poisoning: An update. Fish Tech. News, 11:3-5.

Anggawati, A.M., Fawzya Y, N. dan Putro S. (1984). Studies on histamin contents of cured fishery products. Laporan Penelitian Teknologi Perikanan 33:29-32.

Anonim. 2002. Filter Kimia. O-Fish (Ornamental-Fish Information Service Higlight. http://www.o-fish.com/ Filter/FilterKimia.htm.

AOAC. 1980. Official Methods of Analysis, $13^{\text {th }}$ ed. Assn Official Analytical Chemist. Washington, DC. 1018pp.

Fletcher, G.C., Summers, G., Winchester, R.V. and Wong, R, J. 1995. Histamine and histidine in New Zealand marine fish and shellfish species, particularly kahawai (Arripis trutta). J. Aqua. Food Prod. Technol. 4:533-574

Fletcher, G.C., Summers, G. and Van Veghel, P.W.C.1998. Levels of histamine and histamine-producing bacteria in smoked fish from New Zealand market. J. Food Prot. 61(8): 1064-1070.

Frank, H.A., Yoshiuga, D.H. and Nip, W.K. 1981. Histamine formation and honeycombing decomposition of skipjack tuna, Katsuwonus pelamis, at elevated temperature. Mar. Fish. Rev. 43: 9-14

Hardy, R. and Smith, J.G.M. 1976. The storage of mackerel (Scromber scombrus). Development of histamine and rancidity. J. Sci. Food Agric. 27:595-599.

Kim,S.H., An, H.J. and Price, R.J. 1999. Histamine formation and bacterial spoilage of albacore harvested off the US Northwest Coast. J. Food Sci. 64(2): 340343.

Masayo, O., Shoro, O. and Masaishi, A. 1981. Isolated of psychrophilic histamine forming bacteria from
Scomber japonicus. Bull of the Japanese Soc. of Sci Fish., Japan, 47(12): 1591-1598.

Niven, C.F., Jeffrey, M.B. and Corlett, D.A. 1981. Differential plating medium for quantitative detection of histamine-producing bacteria. Appl. Environ. Microbiol. 41:321-322.

Ozogul, F., Polat, F. and Ozogul, Y. 2004. The effect of modified atmosphere packaging and vacuum packaging on chemical, sensory and microbiological changes of sardines (Sardinella pilchardus). J. Food Chem. 85(1):49-57.

Rawles, D.D, Flick, G.J. and Martin. 1995. Biogenic amines in fish shellfish. Adv. Food. Nutr. Res. 39:329364.

Sally, H. A., Price, R.S. and Brown, W. 1980. Histamine formation by bacteria isolated from skipjack tuna. Bull of the Japanese Soc. of Sci Fish. 46 (8): 991-995.

Sarnianto, P., Irianto, H.E. and Putro, S. 1984. Studies on the histamin contents of fermented fishery products. Laporan Penelitian Teknologi Perikanan 32:3539.

Siang, N.C. and Kim, L.L. 1992. Determination of TMAO$\mathrm{N}, \mathrm{TMA}-\mathrm{N}, \mathrm{TVB}-\mathrm{N}$ by Conway's microdiffusion methods $(1 \%$ boric acid and $0.02 \mathrm{~N} \mathrm{HCl})$ p.B-8.1-B-8.5. In: Miwa, K. and Ji, L.S. (eds.). Lab. Manual on Analytical Methods and Procedures for Fish and Fishery Products. $2^{\text {nd }}$ Mar. Fish. Res. Dep. SEAFDWC, Singapore.

Sikorski, Z.E., Kolakowska, A. and Burt, J.R. 1990. Postharvest Biochem and Microbial changes. p.5575. In: Sikorski, Z.E. (ed.). Seafood: Resource, Nutrition Composition, and Preservation. CRC Press Inc. Boca Raton, $\mathrm{FI}$.

Steel, R.G.D. and Torrie, J.H. 1989. Prinsip dan Prosedur Statistika, $2^{\text {nd }}$ ed. PT. Gramedia, Jakarta. 748 pp.

Wonggo, J. 1995. Pengaruh Perendaman Filet Ikan dalam Air Kelapa terhadap Kandungan Histamin. Tesis Program Pascasarjana KPK IPB-UNSRAT. 64 pp. 


\section{LAMPIRAN 1/APPENDIX 1}

Lembar Penilaian Organoleptik Ikan Pindang/Score Sheet for Sensory Assessment of Boiled Salted Fish

\begin{tabular}{|c|c|c|}
\hline $\begin{array}{l}\text { Faktor yang dinilai/ } \\
\text { Factors to be assessed }\end{array}$ & Diskripsi/Description & $\begin{array}{l}\text { Kode sampell } \\
\text { Sample code }\end{array}$ \\
\hline \multirow[t]{5}{*}{$\begin{array}{l}\text { Penampakan/ } \\
\text { Appearance }\end{array}$} & $\begin{array}{l}\text { 5- utuh, bersih, rapi, menarik/whole, clean, bright, } \\
\text { attractive }\end{array}$ & \\
\hline & $\begin{array}{l}\text { 4- utuh, kurang rapi, bersih, menarik/whole, less bright, } \\
\text { clean, attractive }\end{array}$ & \\
\hline & 3- ada bagian yang pecah/some parts broken & \\
\hline & 2- agak kotor/slightly dirty & \\
\hline & $1-$ kotor/dirty & \\
\hline \multirow[t]{5}{*}{ Bau/Odor } & 5- harum, segar lodoriferous, freshly cooked & \\
\hline & 4- kurang segar/ fresh odours decrease & \\
\hline & $\begin{array}{l}\text { 3-agak bau asam, agak tengik/slightly sour, slightly } \\
\text { rancid, }\end{array}$ & \\
\hline & 2- tengik, basi/rancid, stale & \\
\hline & 1- tengik dan busuk/rancid and spoiled & \\
\hline \multirow[t]{5}{*}{ Rasa/Taste } & 5- enak, gurih, tidak gatal/delicious, tașty, not itchy & \\
\hline & $\begin{array}{l}\text { 4- enak, kurang gurih, tidak gatal/delicious, less tasty, } \\
\text { not itchy }\end{array}$ & \\
\hline & 3- hampir tawar, agak gatal/ nearly plain, slightly itchy & \\
\hline & 2- tidak enak, rasa basi, gatal/not delicious, stale, itchy & \\
\hline & 1- busuk, gatal sekali/spoiled, very itchy & \\
\hline \multirow[t]{5}{*}{ Tekstur/Texture } & 5- utuh, padat, kompak/whole, solid, compact & \\
\hline & 4- retak-retak, padat, kompak/cracking, solid, compact & \\
\hline & $\begin{array}{l}\text { 3- agak berair, longgar, rapuh (agak keras, agak liat)/ sl. } \\
\text { moist, loose, fragile (sl. hard, sl. tough) }\end{array}$ & \\
\hline & 2- basah, berair (keras, liat)/wet, moist (hard, tough) & \\
\hline & $\begin{array}{l}\text { 1- lengket, basah, mudah terurai (sangat keras, sangat } \\
\text { liat)/sticky, wet, easily decompose (very hard, very tough) }\end{array}$ & \\
\hline \multirow[t]{5}{*}{ Lendir/Slime } & 5- tidak berlendir/no slime & \\
\hline & $\begin{array}{l}\text { 4- lendir tipis, tidak jelas, tidak berbau/slime thin, not } \\
\text { transparant, not smelly }\end{array}$ & \\
\hline & 3- lendir agak kental/slime slightly viscous & \\
\hline & 2- lendir basi/slime stale & \\
\hline & 1- lendir busuk/slime spoiled & \\
\hline \multirow{5}{*}{$\begin{array}{l}\text { Penerimaan total/ Total } \\
\text { acceptance }\end{array}$} & 5- sangat suka/very like & \\
\hline & 4- suka/like & \\
\hline & 3- agak suka/slightly like & \\
\hline & 2- tidak suka/dislike & \\
\hline & 1- sangat tidak suka/dislike very much & \\
\hline
\end{tabular}

